\title{
Foreword, special issue: economic analysis of litigations 2
}

\author{
Alain Marciano ${ }^{1} \cdot$ Giovanni Ramello $^{2} \cdot$ Hans-Bernd Schaefer ${ }^{3}$ \\ Published online: 23 July 2020 \\ (c) Springer Science+Business Media, LLC, part of Springer Nature 2020
}

As weird as it seems, it took decades before justice became a relevant topic to law and economics scholarship. Albeit judges and the judicial systems were necessarily on the background of all the analyses focusing on laws, for longtime they were treated as a sort of exogenous features, not affecting the final efficiency of the legal system. They were by default efficient and with no role in determining the final outcomes. Accordingly, they were considered a well-oiled machine efficiently serving the legal system but neither relevant for becoming per se subject matter of autonomous investigation nor affecting the working of legal institutions. What is more, they were essentially considered immune from mundane issues-such as self-interest - characterizing the other individuals — as if judges were not human beings — and as if the legal machinery was not affected by the problems characterizing the other organizations. Judges were thus always supposed to provide the expected resultsactually the best possible ones.

It took thus some time-much more than in other domains, such as politicsbefore was dismantled the "romantic and illusory set of notions" wrapping the working of justice and before looking at it in its reality, how it works and not how it should ideally work with its limits and its possible distortions. It can reasonably be said that the turning point clearly asserting that judges's behavior and that judicial decision-making could be analyzed by using economic tools is Richard Posner's article "What Do Judges and Justices Maximize? (The Same Thing Everybody Else Does)" (1993). It was the paper that finally led scholars to abandon the "romantic" - to paraphrase the words Buchanan used for describing the birth of public choice (Buchanan [1979] 1984, p. 11) —of justice. But it was not the first one. Posner's article is the final step of a long walk in which all the elements needed time for collapsing into an organic perspective (Marciano et al. 2020). Indeed, signals of the incoming revolution were already present in the previous years. It actually started in the late 1960s, with William Landes $(1968,1971)$.

Giovanni Ramello

giovanni.ramello@uniupo.it

1 MRE and University of Montpellier, Montpellier, France

2 DiGSPES, Università del Piemonte Orientale, Alessandria, Italy

3 Bucerius Law School, Hamburg, Germany 
Then, Higgins and Rubin (1980), Cooter (1983) or Cohen (1991)—among others-contributed to the process.

After the publication of Posner's article, almost three decades ago, the law and economics community realized that enforcing institutions should be given a central role in the analysis and scholars worked a lot to disentangle the functioning of legal institutions. Yet, despite the progress in our understanding of the dynamics of the legal system, much more of the work remains to be done. Judicial systems are many and varying according to national legislations-even though there are convergences between them. Often, they are the outcome of a very long historical path in which idiosyncratic elements have been incorporated making thus the jusdicere country specific and worth to be investigated.

This travel into courts, its working, its specific features is very much like to travel into an unexplored land in which it is possible to make many discoveries, to observes peculiar phenomena. What is more, it gives to research the possibility of giving genuine contributions to the scholarly debate. And there is a bunch a unused data that gives the opportunity for doing empirical research.

Today thus the scientific community is increasingly devoting energies and attention to this topic and the law and economics is possibly one of the most involved disciplines. In this vein, we write here on the behalf of well-established group of people spanning in many countries of the world that since almost a decade regularly meets, discusses and fosters publication of researches on the Economics Analysis of litigation. Workshops have taken place in many European cities hosted by well-known academic institutions.

This special issue has been gathered around the workshop organized by HansBernd Schaefer at the Bucerius Law School in Hamburg, one of the leading institutions in Germany in legal education and legal studies whose program for interdisciplinary legal research generously hosted a stage of the scholarly travel. While the meeting has been important for the debate among participants, the special issue is devoted to further spread the results according to a tradition adopted by the group of making available the research to all the community. Several have been the vehicles used for this purpose: the Review of Law and Economics 2015, this journal in 2017 (Volume 44, issue 2) and the Journal of Institution Economics in 2018. However, the European Journal of Law and Economics has an ongoing agenda of attracting good research on the topic and it is happy to create focal points when it possible by means of additional special issues.

Law and economics of litigation, after the first special issue published on 2017, has concerned significant part of the research published on the European Journal of Law and Economics, spanning from judicial decision-making (Sonnemans et al. 2018; Malo et al. 2018; Oytana and Chappe 2018; Hornuf and Klöhn 2019; Clarke and Kozinski 2019) to insolvency procedures and bankruptcy (Mruk et al. 2019; Blazy and Nigam 2019; Staszkiewicz and Morawska 2019) to antitrust enforcement (Gautier and Petit 2018; Cosnita-Langlais and Tropeano 2018; Katsoulacos 2019) to the operating of selected courts of last resort (Kim 2018; López-Laborda et al. 2019) just for citing some of the topics disentangled into the recent contributions on the journal pages. 
With this special issue, we have the opportunity to provide another focal point with new special issue. All the papers were selected through a rigorous review process. The description shortly follows.

Blazy and Stef (2020) extend further the research of bankruptcy by centering the research on post-transition countries. The empirical analysis conducted on determinants of total recovery shows how the emphasis given in general to characteristic of firms should reasonably be shifted, at least partially to the institutional system if one has the possibility to compare different legal settings. The article by Lampach and Dyevre (2020) investigate the factors influencing the choice of domestic judges to pass on cases to the Court of Justice of the European Union. Somehow in Posnerian tradition they we find empirical evidence that the rate at which national courts refer cases is influenced by familiarity with EU law, power-seeking motives and political fragmentation.

Zingg and Elsner's (2020) paper proposes a model of patent disputes which proposes that both settlement and litigation are driven by patent quality. Theoretical findings predict that high quality patents will prevail in court, despite the selection effect at the settlement stage and then the authors test prediction at the litigation stage using a dataset that covers patent litigation in Germany, France and the United.

Ecer et al. (2020) investigates the agreement occurring between branded drug manufacturers and potential generic entrants to settle patent infringement litigation or the threat of such litigation. By means of a rigorous modeling they challenge a current application of Nash bargaining in the antitrust analysis of reverse payment settlements that estimates the bargaining power parameter as the split of the surplus in the actual settlement with alleged reverse payments.

The two last paper have been independently submitted to the journal, they have been reviewed and included in the issue upon permission because the fits very well. The article by Tsikas (2020) explores the impact of stronger enforcing institutions in tax domain on the motivation to voluntarily pay taxes, and how both factors jointly influence tax evasion. It finds that increased deterrence efforts indeed may be associated with less tax evasion.

The paper by Beldowski et al. (2020) concludes the set of papers by proposing a "classical" yet much needed kind of empirical research, that of measuring the performance of courts, which after all are productive facilities. In particular, this article studies the determinants of the performance of commercial district courts in Poland and it uses pooled OLS and stochastic frontier analysis to investigate determinants of court efficiency in resolving cases.

\section{References}

Bełdowski, J., Dąbroś, Ł., \& Wojciechowski, W. (2020). Judges and court performance: A case study of district commercial courts in Poland. European Journal of Law and Economics. https://doi. org/10.1007/s10657-020-09656-4.

Blazy, R., \& Nigam, N. (2019). Corporate insolvency procedures in England: The uneasy case for liquidations. European Journal of Law and Economics, 47, 89-123. https://doi.org/10.1007/s1065 7-018-9599-2. 
Blazy, R., \& Stef, N. (2020). Bankruptcy procedures in the post-transition economies. European Journal of Law and Economics. https://doi.org/10.1007/s10657-019-09634-5.

Buchanan, J. M. (1979) [1984]. "Politics without Romance: A Sketch of Positive Public Choice Theory and Its Normative Implications". Inaugural lecture, Institute for Advanced Studies, Vienna, Austria. Zeitschrift des Instituts für Höhere Studien 3: B1-B11. In J. M. Buchanan and D. T. Robert (Eds.), The Theory of Public Choice-II (pp. 11-22). Ann Arbor, MI: University of Michigan Press.

Clarke, C., \& Kozinski, A. (2019). Does law and economics help decide cases? European Journal of Law and Economics, 48, 89-111. https://doi.org/10.1007/s10657-019-09613-w.

Cohen, M. A. (1991). Explaining judicial behavior or what's 'unconstituitional' about the sentencing commission? Journal of Law Economics and Organization, 7(1), 183-199.

Cooter, R. D. (1983). The objectives of private and public judges. Public Choice, 41(1), 107-132.

Cosnita-Langlais, A., \& Tropeano, J. (2018). How procedures shape substance: Institutional design and antitrust evidentiary standards. European Journal of Law and Economics, 46, 143-164. https://doi.org/10.1007/s10657-018-9574-y.

Ecer, S., Montes, R., \& Weiskopf, D. (2020). On the application of Nash bargaining in reverse payment cases in the pharmaceutical industry. European Journal of Law and Economics. https://doi. org/10.1007/s10657-020-09661-7.

Gautier, A., \& Petit, N. (2018). Optimal enforcement of competition policy: The commitments procedure under uncertainty. European Journal of Law and Economics, 45, 195-224. https://doi. org/10.1007/s10657-018-9578-7.

Higgins, R. S., \& Rubin, P. H. (1980). Judicial discretion. Journal of Legal Studies, 9(1), 129-138.

Hornuf, L., \& Klöhn, L. (2019). Do judges hate speculators? European Journal of Law and Economics, 47, 147-169. https://doi.org/10.1007/s10657-018-09608-z.

Katsoulacos, Y. (2019). On the choice of legal standards: A positive theory for comparative analysis. European Journal of Law and Economics, 48, 125-165. https://doi.org/10.1007/s10657-01909616-7.

Kim, C. (2018). Judge's gate-keeping power and deterrence of negligent acts: An economic analysis of Twombly and Iqbal. European Journal of Law and Economics, 46, 39-66. https://doi. org/10.1007/s10657-018-9590-y.

Lampach, N., \& Dyevre, A. (2020). Choosing for Europe: Judicial incentives and legal integration in the European Union. European Journal of Law and Economics. https://doi.org/10.1007/s1065 7-019-09622-9.

Landes, W. (1968). The economics of fair employment law. Journal of Political Economy, 76(4), $507-552$.

Landes, W. (1971). An economic analysis of the courts. Journal of Law and Economics, 14(1), 61-107.

López-Laborda, J., Rodrigo, F., \& Sanz-Arcega, E. (2019). Consensus and dissent in the resolution of conflicts of competence by the Spanish Constitutional Court: The role of federalism and ideology. European Journal of Law and Economics, 48, 305-330. https://doi.org/10.1007/s1065 7-019-09631-8.

Malo, M. Á., Martín-Román, Á., \& Moral, A. (2018). "Peer effects" or "quasi-peer effects" in Spanish labour court rulings. European Journal of Law and Economics, 45, 497-525. https://doi. org/10.1007/s10657-018-9576-9.

Marciano, A., Melcarne, A., \& Ramello, G. B. (2020). Justice without romance: The history of the economic analyses of judges' behavior, 1960-1993. Journal of the History of Economic Thought, 42(2), 261-282.

Mruk, E., Aguiar-Díaz, I., \& Ruiz-Mallorquí, M. V. (2019). Use of formal insolvency procedure and judicial efficiency in Spain. European Journal of Law and Economics, 47, 435-470. https://doi. org/10.1007/s10657-019-09621-w.

Oytana, Y., \& Chappe, N. (2018). Expert opinion in a tort litigation game. European Journal of Law and Economics, 46, 67-107. https://doi.org/10.1007/s10657-018-9584-9.

Posner, R. A. (1993). What do judges and justices maximize? (The same thing everyone else does). Supreme Court Economic Review, 3, 1-41.

Sonnemans, J., van Dijk, F., Donders, B., et al. (2018). An economic approach on countering the misuse of the right to challenge judges: An experiment. European Journal of Law and Economics, 45, 29-57. https://doi.org/10.1007/s10657-016-9539-y. 
Staszkiewicz, P., \& Morawska, S. (2019). The efficiency of bankruptcy law: Evidence of creditor protection in Poland. European Journal of Law and Economics, 48, 365-383. https://doi. org/10.1007/s10657-019-09629-2.

Tsikas, S. A. (2020). Enforce taxes, but cautiously: Societal implications of the slippery slope framework. European Journal of Law and Economics. https://doi.org/10.1007/s10657-020-09660-8.

Zingg, R., \& Elsner, E. (2020). Protection heterogeneity in a harmonized European patent system. European Journal of Law and Economics. https://doi.org/10.1007/s10657-020-09651-9.

Publisher's Note Springer Nature remains neutral with regard to jurisdictional claims in published maps and institutional affiliations. 